44 Justus AN, Finn PR. Startle modulation in non-incarcerated men and women with psychopathic traits. Pers Individ Dif 2007; 43: 2057-71.

45 O'Leary MM, Loney BR, Eckel LA. Gender differences in the association between psychopathic personality traits and cortisol response to induced stress. Psychoneuroendocrinology 2007; 32: 183-91.

46 Hester R, Fassbender C, Garavan H. Individual differences in error processing: a review and reanalysis of three event-related $\mathrm{fMRI}$ studies using the GO/NO GO task. Cereb Cortex 2004; 14: 986-94.

47 Soderstrom $\mathrm{H}$, Hultin L, Tullberg M, Wikkelso C, Ekholm S, Forsman A. Reduced frontotemporalperfusion in psychopathic personality. Psychiatry Res 2002; 114: 81-94.

48 Delgado MR. Rewardrelated responses in the human striatum. Ann N Y Acad Sci 2007; 1104: 70-88.

49 Mink JW. The basal ganglia: focused selection and inhibition of competing motor programs. Prog Neurobiol 1996; 50: 381-425.

50 Redgrave P, Prescott TJ, Gurney K. The basal ganglia: a vertebrate solution to the selection problem. Neuroscience 1999; 89: 1009-23.
51 Casey BJ, Forman SD, Franzen P, Berkowitz A, Braver TS, Nystrom LE, et al. Sensitivity of prefrontal cortex to changes in target probability: a functional MRI study. Hum Brain Mapp 2001; 13: 26-33.

52 Casey BJ, Thomas KM, Davidson MC, Kunz K, Franzen PL. Dissociating striatal and hippocampal function developmentally with a stimulusresponse compatibility task. J Neurosci 2002; 22: 8647-52.

53 Peterson BS, Kane MJ, Alexander GM, Lacadie C, Skudlarski P, Leung HC, et al. An event-related functional MRI study comparing interference effects in the Simon and Stroop tasks. Brain Res 2002; 13: 427-40.

54 Durston S, Thomas KM, Worden MS, Yang Y, Casey BJ. The effect of preceding context on inhibition: an event-related fMRI study. Neurolmage 2002; 16: 449-53.

55 Durston S, Davidson MC, Thomas KM, Worden MS, Tottenham N, Martinez A, et al. Parametric manipulation of conflict and response competition using rapid mixed trial event-related fMRI. Neurolmage 2003; 20: 2135-41.

56 Brown SM, Manuck SB, Flory JD, Hariri AR. Neural basis of individual differences in impulsivity: contributions of corticolimbic circuits for behavioural arousal and control. Emotion 2006; 6: 239-45.

कि EXTRA

\title{
The Bipolar World Within Us
}

\author{
Jenny Wells
}

Love and hate, generous and greedy

Kind and cruel, independent and needy

Lead and follow, good and bad

Release and hold, happy and sad

Optimist and pessimist, high and low

Child and adult, yes and no

Honest and dishonest, weak and strong

Content and jealous, right and wrong

Help and hinder, shallow and deep

Silent and loud, sow and reap

Healthy and ill, busy and lazy

Certain and doubt, sane and crazy

Laugh and cry, fall and rise

Sweet and bitter, ignorant and wise

Passive and aggressive, cool and warm

Give and take, calm and storm

Feminine and masculine, joy and pain

Saint and sinner, modest and vain

Clever and foolish, slow and fast

Change and stagnate, fail and pass

Teacher and student, young and old

courage and fear, shy and bold.

Born in Kent, I spent most of my early life in Aberystwyth and now live in Cornwall with my husband and our son. I was diagnosed with bipolar disorder in 1994 at the age of 33. It was very confusing, especially for my family, as I was manic and oblivious. I was heavily medicated for nearly 2 years, which made me emotionally numb, and I had been admitted to psychiatric hospitals three times, last time in 1997. I have had many episodes since, though I learnt to control the illness to some extent and I rarely have lows, mostly highs. Many positive things have happened since my diagnosis - I now work for a local mental health charity, helping to eradicate the stigma associated with mental ill health; I hope that my poems are a way of doing this also. 